\title{
Financial development and tourism at the traditional village in Gianyar, Bali: Tri Hita Karana Value
}

\author{
I Made Suidarma*; I Ketut Nurcita; I Dewa Nyoman Marsudiana
}

Universitas Pendidikan Nasional, Bali, Indonesia

*To whom correspondence should be addressed. Email: suidarma@ undiknas.ac.id

\begin{tabular}{|l|l|l|l|l|}
\hline DOI: & Received: & Revised: & Accepted: & Published: \\
10.22437/ppd.v8i6.10891 & 03.11 .2020 & 08.01 .2021 & 10.01 .2021 & 01.02 .2021 \\
\hline
\end{tabular}

\begin{abstract}
.
Tri Hita Karana (THK) is the foundation and guide of the general Hinduism society in living their life. This study aims to identify THK integration on the synergy Village Credit Institution (LPD) and traditional village and observe the LPD contribution in the financial and tourism development at the traditional village in Gianyar, Bali. An ethnography approach was used to identify the problem. The result found that THK has a substantial role in the existence of LPD, which contributes to the traditional village development, especially in Gianyar. The existence of LPD also contributes significantly to the village's financial development, and the existence of LPD could have a significant impact on society's knowledge and access to financial and services and promoting the regional tourism potential. This effort is also a form of strengthening and maintaining the sustainable existence of traditional village tourism and improving LPD performance in terms of financing and financial management of traditional villages
\end{abstract}

Keywords: Ethnography, Social capital, Tourism, Tri Hita Karana

JEL Classification: O18, O35, Z13

\section{INTRODUCTION}

Local Government Regulation of Bali Province, Number 3 of 2007 concerning the Village Credit Institution (LPD), stated that village credit's significance is to empower and create welfare for the traditional society. It especially for the pakraman (traditional village), which could benefit social, economic, and culture. The increase in LPD assets (which 20.5\%) shows a high level of public trust in LDP (Cendekiawan, 2015).

The existence of pakraman as one of the driving factors of the tourism sector is quite important to notice. The existence of pakraman as one of the cultural assets and the effort to maintain Bali's local wisdom also drives the tourism sector and other sectors such as Micro Small and Medium Enterprises (MSMEs), service, and transportation.

Several previous studies have been conducted to highlight the role of LPD in the tourism sector, especially pakraman. One of those studies is Arka (2016). His study result showed that there must be several improvements in performance, management, and responsibility on the pakraman village assets. Besides, there was a study to observe the LPD performance by implementing the Tri Hita Karana (THK) concept conducted by Mulyawan et al. (2017). The result showed that the THK concept strongly influenced 
the LPD performance through the Good Corporate Governance approach. The society and traditional organization in Bali always put forward the THK concept in every activity. The THK concept integrates cultural and religious values, which are strongly attached to Balinese society.

This study will review the THK concept's existence related to its contribution to LPD in the tourism sector, especially the pakraman in Gianyar. The study related to this problem is still relatively rare that it urges the writer to conduct a study on it.

\section{METHODS}

This study used a qualitative method through ethnography. This method will search for further information related to the role of Bali society's tradition and culture. Particularly its application on the LPD performance in contributing to help the tourism development at the pakraman

This study obtained information from several related sources, among others, from the LPD in the Gianyar Regency. Information was explored regarding the THK concept's role in creating the sustainability and existence of LPD. The research sample was selected based on the potential and good performance of the LPD. Information can be obtained on how LPD management is integrated with THK values to maintain its existence and benefit the surrounding community.

This study will identify the role of three main elements of the THK concept, which covers Prahyangan, Pawongan, and Plemahan in the LPD performance on the service and access of the pakraman. Ethnography is an approach method used to describe the unique cultural society (Fetterman, 1998; Sangasubana, 2011). According to Angrosino (2007) and Hogan et al. (2009), ethnography researchers will observe the predictable human behavior pattern through research object experience by participating in the research object life to seek further cultural sides application daily.

\section{RESULTS AND DISCUSSION}

\section{Tri Hita Karana (THK) and Village Credit Institution (LPD)}

The traditional village is the customary law society unit which has a region, position, original structure, traditional rights, independent wealth, tradition, society life etiquette across generations bounded to the holy place (kahyangan tiga or kahyangan desa), duty and authority, as well as the right to rule and regulate it's household (Local Government Regulation of Bali Province Number 4 of 2019 Article 1 concerning the traditional village of Bali)

The traditional village implementation also functions to strengthen the THK concept as the Hinduism society's concept and guide. The traditional village arrangement has several functions as: a) Parahyangan, Pawongan, and Palemahan of the traditional village; b) customary law system and implementation; c) Sabha and Kerta organization of the traditional village; d) Development organization of custom, religious, tradition, art and culture, as well as the local wisdom of the traditional village society; e) Pasraman as the Hinduism-based educational institution for developing personal characters, moral integrity, and the social quality of Bali; f) Traditional village security organization; g) traditional village economy organization.

The THK concept becomes a guideline in managing traditional villages integrated with the Balinese people's local wisdom. Those provided the existence in maintaining the traditional village existence and the whole traditional organization in Bali such as Subak, LPD, etc. The religious elements supported by strong social capital will strongly 
drive the society from their deepest heart to maintain and apply the preserved value and norm.

In the Local Government Regulation of Bali Province, Number 4 of 2019, the Balinese traditional village's main elements (Parahyangan, Pawongan, Palemahan) were THK philosophy representatives. The THK philosophy concept covers: a) Bhakti karma (karmic devotion) to the Hyang Widhi Wasa (The One God); b) Togetherness, care, and punia (loyalty) between Krama (community members) and peers; and c) Congeniality, harmony, and asih krama (mercy) to nature and the environment.

LPD becomes the alternative to guarantee the traditional welfare society, which was the karma of the pakraman. LPD has been authorized, and the existence has been regulated based on the Local Government Regulation of Bali Province.

Those amendments were conducted since the previous regulation is no longer suitable to society's real condition that it needs to be updated and amended. LPD is the traditional village's financial institution, which took a position in the traditional village's wewidangan (authority). In the LPD organizational system, a Prajuru is the operations officer of the LPD. Panureksa is the traditional village's internal oversight unit, which functions to oversee the LPD management. Besides, in its working system, LPD also has an operational plan and the revenue and expenditures budget plan LPD, which has its mechanism and has been regulated in the LPD regulation.

The net profit of LPD will be shared at the end of the determined financial year. It covers capital reserve for $60 \%$, village society development and empowerment fund for $20 \%$, production service for $10 \%$, empowerment fund for $5 \%$, and social fund for $5 \%$.

LPD in Bali has a very contributive potential for the traditional village existence development. Its dominant role in managing finance by referring to Bali's social and cultural order could synergize well in responding to the traditional village needs. LPD in Bali has a significant development, which could be seen in 2017 in the middle of economic growth deceleration of Bali by showing asset total, which increased by $22 \%$ in 2017.

Bali's LP empowerment institute (LP-LPD) has booked the LPD assets that have reached Rp19,2 trillion in April 2018 (Bisnis Bali, 2018). This increase showed a very well growth than the previous quarter at the end of 2017 with Rp18,47 trillion assets. It showed that the performance of LPD in Bali also provides acceleration and financial assistance such as the formal financial institution like the other banking sectors.

I Nyoman Arnaya SE (the head of LP-LPD Bali) mentioned that LPD in Bali contributes significantly to the society's needs, especially the karma of traditional village. The form of $20 \%$ profit was provided to develop the traditional village or the $5 \%$ profit, which was allotted for social activity. Besides, the existence of LPD could also employ up to 7,977 people. This condition showed that the existence of LPD did fulfill the village's social-economic needs and employed the workforce. It added a positive value to the employment condition in Bali Province and its surroundings.

The good performance of LPD was inseparable from the role of related stakeholders such as the LPD committee, village society (traditional village krama) as the customer. The strong trust dedicated to LPD is given by the traditional village karma that many people decided to save their money and take a loan from LPD. The trust element built between the traditional society and LPD gave a positive synergy for the existence of LPD until now. Besides, professional management such as the audit conducted in the asset management and other activities of LPD becomes one of the factors that increase public's trust. 
The LPD asset growth was also supported by the high lending increase, which reached $18.2 \%$ or Rp13.14 trillion, which increased from Rp11.12 trillion in the previous period. It impacted the customer increase for 429,693 and a significant increase in the third parties fund. The savings and deposits increased consecutively by $34.7 \%$ and 37.6\% (Bisnis Bali, 2018). Several banking instruments of LPD adequately showed the LPD performance, which contributed to Bali's economic flow, especially at the village society. LPD asset ownership was dominated by the asset ownership above Rp5 billion for $49,47 \%$ of the total number of PD or around 514 units. While the asset ownership below Rp1 billion was $27,56 \%$ or around 350 units of LPD and asset in between Rp 1 billion up to Rp 5 billion was 31,97\% or 406 units of LPD. It showed that the current condition of LPD has great potential in contributing to Bali's economic development and dynamics.

Still, the LPD with great assets has not yet been distributed evenly in each region in Bali. The LPD with great asset distribution was still around Badung, Denpasar, and Gianyar regions with higher and busier activities than the other regions. Based on the report of LP-LPD, total asset ownership of LPD in Badung in 2017 reached Rp5.9 trillion, Gianyar reached Rp3.6 trillion, and Denpasar was Rp1.9 trillion.

Besides Badung and Denpasar, Gianyar also had a good performance than the other regions. The stakeholder also supported the positive performance either from LPD or society. To maintain performance stability, LPD in Gianyar always conducts an annual routine evaluation to find out the LPD development and growth in a more detailed way. The detailed audit is also carried out to determine the small or big problem gaps to be responded to and handled immediately. This evaluation is also carried out by making a transparent report of the LPD performance to society. It will increase the public's trust, which has become the main contributor to Bali's LPD success in general, especially in Gianyar.

The performance of LPD in Gianyar was also shown by the increased total LPD asset by $30,02 \%$ from 2010 to 2011 with the previous total asset Rp940,8 million into Rp1,2 billion. The increase was also supported by the increased term deposits from 2010 to 2011 for $31,14 \%$ and increased credits for $22,02 \%$. It influenced the LPD profit increase by $19,27 \%$. Then, $20 \%$ of the profit will be allotted to traditional village development. However, the performance increase had one flaw that could decrease the customer's number previously 88.204 in 2010 to 86.411 in 2011.

\section{Integration of THK concept on LPD}

\section{The element of parahyangan}

The element of parahyangan is an essential element in the THK concept, which explains the harmony between humans and the creator. In this case, the relationship between krama and the One God.

Bali's public organization or institution is always symbolized by a temple that is identical to a worship place. Temple is considered a place with a high cultural value. The temple has a high spiritual value as the worship place and creates harmony between humans and God.

The temple can also be used as the LPD committee supervisor, such as panureksa (LPD Internal Auditor) or prajuru (LPD Operational Committee). When their behavior starts to be off track of the social, cultural, and spiritual order, the temple could remind them that each of their behavior is watched by God and must be more devoted to God.

The Balinese society's pursuance to God in the THK philosophy is stated in the 
element of Parahyangan, where the harmony between God and human being always become their main spiritual need. It is also based on trustworthiness, which becomes the main foundation in an ideal relationship with God or peers humans to create sustainability and harmony.

The krama of the traditional village adopts a similar concept. LPD always involves God in conducting their activities. It was showed by conducting the ceremony to reciting prayers lead by the LPD committee to start their activity by expecting safety, protection, and smoothness in managing the LPD.

In operating LPD, the parahyangan element did not only conduct worship or pray to ask for protection, safety, and smoothness to God but also to donate the LPD profit to help the traditional ceremony funding.

The parahyangan element, which is integrated into the LPD activities such as prayers and ceremonies conducted in managing LPD, becomes one of the key success and existence of LPD in Bali. It is based on the intrinsic value such as the high and deep-rooted spirituality that they will always be obedient and devoted to God. It will remove the negative action such as corruption in managing LPD. Besides, this will grow the trust between LPD and traditional village krama to manage the society's fund or the village krama; either the krama will be the customer or debtor of the LPD.

\section{The element of pawongan}

Pawongan reflects the horizontal relationship of human beings and their peers either in the organization's internal or external. This relationship exists as the result of cooperation, a condition where they need each other, mutual assistance resulting from uncertainty or extinction that the relationship is created (Windia and Dewi, 2011).

Human characteristics tend to maintain and build a relationship within a community. The Pawongan element aspect is one of the human efforts to maintain a relationship within the community in an activity they carry out together. It is similar to the Hinduism lesson that humans shall achieve the jagathita, which means a condition where there built a good relationship of good actions, material, joy, and balance or in Hinduism terms, they are called dharma, artha, kama, and moksha.

In managing LPD, the traditional village also involves the society element or village krama, either the LPD committee or the traditional village committee. The society's involvement is not limited to the role merely as customer and committee of the LPD. However, they can be the operational subject and object in the LPD management. In this case, Society is the village krama and participates in supervising the LPD management internally or externally from various angles. The supervision could be carried out by being a customer or the general village krama.

One of the forms of pawongan relationships among humans is mutual and independent assistance. Such as in building a holy place like the temple and any religious activities, they try to conduct it independently. Besides, the form of pawongan element in LPD and the traditional village was shown by the synergy between village krama and LPD.

Besides, the establishment of LPD in the pakraman reflects the pawongan element in the traditional village society. The existence of LPD is a form of the social relations of the society that interacts with each other to create an organization that provides financial services to the village society.

The dynamics and shift of the life pattern and economy impact the socioeconomic condition. To respond to such conditions requires an accessible financial service that provides effective and efficient service based on Bali society's socio- 
cultural life.

Interaction between LPD and pakraman also represents the social interaction in the pawongan element. The interaction harmony happens between the LPD committee and village krama in providing funding service for the society.

Most of society also finishes any social or economic problems through discussion and mutual assistance. The interaction intensity of the traditional village society is still preserved and strongly related to the social order deeply rooted within them. The LPD participation is reflected through the support of LPD on activities conducted by the village krama, although LPD does not fully take a role in it. Besides the interaction between LPD and village krama, social relationship happens between an LPD and the other LPD, regional government, or academician in the Bali region.

Meanwhile, the human resource competency in several LPD has not yet been adequate to accommodate the LPD needs that it impacted the LPD operational gridlock. Besides, the society's mindset influenced them to utilize the LPD access and service for consumptive activity instead of the productive one. Sometimes it becomes one of the problems in LPD, resulting in bad credit and other problems. To respond to the situation, the government initiates to conduct socialization concerning the LPD management in a good, effective, and efficient way without removing the socio-cultural elements in society.

The involvement of academician, practitioner, or culture enthusiast in several activities also involves LPD as the form of the established social interaction and the reflection of pawongan element in the THK concept. It is also based on the deep-rooted social capital within Bali society that discussion and mutual assistance will be the absolute way to solve problems in society.

The social capital concept is called linking, establishing relationships or social interactions between the internal and external parties, the LPD and government, practitioner, academician, or culture enthusiast. This interaction contributes to every problem of the LPD, either on the cultural, social, or economic side.

In its practice, LPD also provides funding for human resource development through credit for educational purposes. The poor krama who needs to pay the tuition fee could take the credit service. Usually, the krama used by the krama who's the family work overseas got the collateral to pay the credit. The installment could be paid when they got back from overseas or when they sent the money.

This kind of practice has been practiced many times, and there was a minimum bad credit because they implement a strong THK concept. Between LPD and the village, krama could build a high trust based on the spiritual element and believed that karma exists. When a customer becomes irresponsible, they believe that bad things happen to the customer. This belief has been deep-rooted within their mind that it influences them always to perform good deeds.

\section{The element of palemahan}

Bali's society believes that if humans could live in harmony with nature, then nature will protect them in return and provide the best potential. LPD is also concerned with the surrounding environment to maintain the village's natural environment sustainability. The form of action carried out by LPD to fulfill the Palemahan element is establishing a Waste Management Unit (UPS) and waste bank.

The UPS is aimed to collect either organic or inorganic trash. The waste bank is aimed to collect and manage the trash collected by UPS. Waste is managed based on its type. Inorganic waste (especially plastic waste) is recycled into art crafts. Organic waste 
is used as fertilizer or other environmentally friendly planting materials.

LPD takes the environment management funding role and contributes to the village's spatial arrangement to maintain natural sustainability. The society also conducts some weekly routines such as mutual assistance to clean the traditional village environment to maintain the environment cleanliness. In this case, LPD contributes to the society's activity by providing help or funds as a form of care to the environment.

LPD also contributes to the reforestation in the villages by planting trees that can be the green zone. Besides creating a beautiful and comfortable atmosphere, reforestation can also maintain natural environment sustainability.

\section{CONCLUSIONS AND RECOMMENDATIONS}

\section{Conclusions}

Tri Hita Karana's philosophy as the foundation and reference for the Hinduism society in general in carrying out the activities has a strong role in the existence of LPD, which contributes to the traditional village development, especially in Gianyar Regency. It was reflected through several social activities supported by LPD, either from the funding, fostering, and empowerment of all aspects of the THK elements, namely parahyangan, pawongan, and palemahan.

The existence of LPD could contribute significantly to financial development in the rural area. It was supported by the social capital and trustworthiness established between the traditional village krama and the whole LPD committees that create sustainability that maintains the LPD development existence in Gianyar, Bali.

Besides pushing financial development, LPD also contributes to the tourism sector development and other supporting sectors. It was reflected through the funding or providing capital for the tourism business owner. LPD also fosters the village's tourism potential innovations and promotes their region's tourism potential.

\section{Recommendations}

In the current age of technology, LPD needs to integrate technology to develop financial management by upholding the tradition, culture, and THK philosophy. It is used to improve the LPD efficiency and effectiveness in carrying out the service and ease of access to society.

Besides, LPD needs to coordinate more intensively to share the knowledge to find out and observe further village potential and share the suggestion in managing the human resource that all LPD could operate well. In this case, LPD shall coordinate with the academicians, culture observers, or practitioners to help determine the village and LPD management's further potential.

\section{ACKNOWLEDGMENT} Indonesia.

Thank you we say to Universitas Pendidikan Nasional, Denpasar, Bali

\section{REFERENCES}

Angrosino, M. (2007). Doing ethnographic and observational research. Thousand Oaks, CA: Sage.

Arka, I.W. (2016). Eksistensi Lembaga Perkreditan Desa dalam Pembangunan Desa Pekraman sebagai Desa Wisata di Bali. GaneÇ Swara, 10(2), 78-84

Bendesa, I K.G. M.A.D.E., Meydianawathi. L.D, Nata, I. K.S., Arka, S., \& Saientisna, 
M.D. (2013). Peran Lembaga Perkreditan Desa Di Bali : Pendekatan Index of Financial Inclusion. Jurusan Ekonomi Pembangunan Fakultas Ekonomi Universitas Udayana

Cendekiawan. (2015). Aset lembaga perkreditan desa di Bali melonjak. Available at: https://kabar24.bisnis.com/read/ 20150121/78/393664/aset-lembaga-perkreditandesa-di-bali-melonjak-205

Fetterman, D.M. (1998). Ethnography: Step by step (2nd ed.). Thousand Oaks, CA: Sage

Katircioglu, S., Katircioğlu, S. \& Altinay, M. (2017). Interactions between tourism and financial sector development: evidence from Turkey. The Service Industries Journal, 38(9-10), 519-524

Kurniasari, T.W. (2007). Lembaga Perkreditan Desa (LPD) Dalam Perspektif Hukum : Sebuah Lembaga Keuangan Adat Hindu Penggerak Usaha Sektor Informal di Bali. Jurnal Masyarakat dan Budaya, 9(1), 53-78

Mulyawan, I.P.A., Wirama, D.G., \& Badera, I.D.N. (2017). Budaya Tri Hita Karana Sebagai Pemoderasi Pengaruh Prinsip Good Corporate Governance Pada Kinerja Lembaga Perkreditan Desa di Kota Denpasar. E-Jurnal Ekonomi dan Bisnis Universitas Udayana, 6(8), 3193-3222

Ohlan, R. (2017). The relationship between tourism, financial development and economic growth in India', Future Business Journal. 3(1), 9-22. doi: 10.1016/j.fbj.2017.01.003.

Peraturan Daerah Provinsi Bali Nomor 3 Tahun 2007 tentang Lembaga Perkreditan Desa (LPD).

Peraturan Daerah Provinsi Bali Nomor 3 Tahun 2017 Tentang Lembaga Perkreditan Desa

Peraturan Daerah Provinsi Bali Nomor 4 Tahun 2019 Tentang Desa Adat Di Bali

Saidharta. A.A.N.G. (2017) Lembaga perkreditan desa sebagai penopang ke-ajegan budaya ekonomi masyarakat Bali. Jurnal Kajian Bali, 7(2), 1-18

Sangasubana, N. 2011. How to Conduct Ethnographic Research. The Qualitative Report, 16(2), 567-573. https://doi.org/10.1017/CBO9781107415324.004

Suhel, S. \& Bashir, A. (2018) The role of tourism toward economic growth in the local economy. Economic Journal of Emerging Markets, 10(1), 32-39. doi: 10.20885/ejem.vol10.iss1.art4.

Torres-delgado, A. \& Palomeque, F. L. (2012). The growth and spread of the concept of sustainable tourism: The contribution of institutional initiatives to tourism policy. Tourism Management Perspectives. 4, 1-10. doi: 10.1016/j.tmp.2012.05.001.

Windia, W. \& Dewi. R.K. (2011). Analisis Bisnis Berlandaskan Tri Hita Karana. Bali: Udayana University Press.

(C) 2021 by the authors. Licensee JPPD, Indonesia. This article is an open-access article distributed under the terms and conditions of the Creative Commons Attribution (CC BY) license (http://creativecommons.org/licenses/by/4.0/). 